\title{
Switching Intentions among Millennial Banking Customers to Fintech Lending
}

\author{
Muhammad Anif Afandi \\ Universitas Muhammadiyah Metro, Indonesia \\ Corresponding email: afandianif@gmail.com
}

\begin{abstract}
The purpose of this study is to analyze of switching intentions among millennial banking customers to the financing services of fintech lending in Indonesia using the PPM framework. 245 primary data were collected by Likert 5 scale category which was subsequently conducted data analysis using the OLS method. The results showed that in the perspective of push effects, all factors have no significant effect on switching intentions or in other words the millennial banking customers have considered that credit/financing services in banking is quite good that it does not encourage them to switch. In the perspective of pull effects, ease of use and pricing benefit factors of fintech lending have significant effect on switching intentions so that it attracts them to switch. Meanwhile, in the perspective of mooring effects, the factors of service products and reputation significantly affect switching intentions so as to impede them to switch. In addition, Islamic banking customers are known to have higher potential to switch to the financing services of fintech lending. The results of this study provide useful information for the banking industry, fintech lending and regulators to be able to develop strategies and effective policies amid the potential of customer switching.
\end{abstract}

Keywords: Switching Intentions, Banking, Fintech Lending, Millennial, PPM. JEL Classification: G4; M3.

@ IJIEF 2020 published by Universitas Muhammadiyah Yogyakarta, Indonesia All rights reserved

DOI:

https://doi.org/10.18196/ijief.3230
Web:

https://journal.umy.ac.id/index.php/ijief/article/view/8955

Citation:

Afandi, M. A. (2020). Switching Intentions Among Millennial Banking Customers to Fintech Lending. IJIEF: International Journal of Islamic Economics and Finance, 3(2),283-304. DOI: https://doi.org/10.18196/ijief.3230 
Afandi $\mid$ Switching Intentions among Millennial Banking Customers to Fintech Lending

\section{Introduction}

\subsection{Background}

The 4.0 Industrial Revolution is the integrated physical, digital and biological world that spawned artificial intelligence, Internet of Things (IoT), autonomous vehicles, 3D printing, nanotechnology, biotechnology, quantum computing and others (Schwab, 2016). One of the biggest achievements of the 4.0 Industrial Revolution is the development of technology. The rapid development of technology resulted in many activities of human life experiencing changes such as browsing, connectivity, shopping and even ordering taxis can now be done using only devices such as smartphones or websites run through the internet network.

The ease and speed offered by the technology leads to a phenomenon called disruption. According to Kasali (2018), disruption interpreted as a change that occurred as a result of future presence to the present through the presence of something new and changed something that has been running normally. One of the novelties of disruption phenomenon is the emergence of new business model company called new-entrants which are disrupted their business model of incumbent companies from all aspects of the business process include production, consumption, transportation and distribution (Schwab, 2016).

One industry that is predicted to be disrupted with the presence of new business model of new-entrant companies is the banking industry with the presence of similar industries that utilize technology as its competitive advantage called Financial Technology (Fintech). According to PricewaterhouseCoopers (2016), the banking industry is predicted to be disrupted by Fintech in four categories namely market share, margin, information system security and customer switching. In addition, due to the ability of Fintech to reach micro clients more broadly, predicted to reduce the banking revenue by $10-40$ percent in 2025 (Dietz et al., 2016).

The switching of banking customers as in the explanation of Price Waterhouse Coopers (2016) is needed scientifically proven through study to be able to know the factors that affect it. However, study on the factors affecting of switching intentions among banking clients to the financing services of Fintech lending tends to be limited as done by Maier (2016). However, Maier (2016) examined about the phenomenon of customer switching in banking to crowdlending financing services using the research object of MSMEs and analysts using four dimensions namely technical dimension, functional dimension, image and innovativeness.

Other studies that discuss the phenomenon of banking customers to the financing services of Fintech lending tend to still be segmented in each sector, such as the customer switching from bank one to another bank or from one type of Fintech to other types of Fintech such as the studies conducted by Al-hawari (2014), Vyas and Raitani (2014), Piha and Avlonitis 
Afandi $\mid$ Switching Intentions among Millennial Banking Customers to Fintech Lending

(2015), Bakar et al. (2016), Farah (2017a), Farah (2017b), Koutsothanassi et al. (2017), Lee et al. (2019) and Le Wang et al. (2019).

In addition, in earlier studies, it is still very rare that the literature focuses on the phenomenon of customer switching on banking to the Fintech lending services by using the category of millennial clients. In fact, based on the report of TransferWise (2016), the increasing in the number of millennials is one of the causes of receiving Fintech industry as a new player in financial industry market beside other factors such as the declining in banking customer trust due to the global financial crisis of 2008, better expectations of Fintech industry, the increasing in the use of mobile Internet and the regulation that support Fintech existence. In addition, millennials are the largest proportion of Indonesians to reach 33.75 percent or amounting to 88 million people that should be the largest consumer target of the financial industry (KPPPA and BPS, 2018).

\subsection{Objectives of the Research}

Based on the discussion above, because of the gap that the previous studies discussing the customer switching in banking to the financing services of Fintech lending is still very limited and segmented in each sector as well as the lack of studies that focuses on the millennial generation, then this study is conducted to examine and analyze comprehensively regarding the phenomenon of customer switching in banking to the financing services of Fintech lending with customer object of millennial category. The results of this study are beneficial to the management of the banking industry, Fintech lending and regulators in order to determine the best strategies or policies in the midst of the potential of customer switching.

This study proceeds several discussions as follows. Section II discusses regarding literature review including the theory used, previous studies, hypothesis development dan conceptual framework. Section III discusses the methodology used. In the section IV, we discuss the results and analysis and then finally in the section $V$, we formulate our conclusion and recommendation.

\section{Literature Review}

\subsection{Customer Switching in the Context of Push-Pull- Mooring (PPM) Framework}

One theory that discusses the phenomenon of customer switching is the Push-Push-Mooring (PPM) theory. The PPM theory was developed by Bansal et al. (2005), which adopted the theory of human migration in geography. If in the concept of human migration, someone moved from one place to another, then in the context of customer switching then a customer moved from one service provider to another service provider (Bansal et al., 2005). 
Afandi $\mid$ Switching Intentions among Millennial Banking Customers to Fintech Lending

The PPM theory consists of three effects namely push effect, pull effect and mooring effect. The push effect is a negative factor of the services used today that encourage customers to switch to other services that are considered better. The pull effect is a positive factor of the intended service that attracts customers to switch to the previously used services. Meanwhile, the mooring effect is a factor that inhibits the movement of customers (Bansal et al., 2005).

In this study, modifications were made to each factor in PPM theory based on previous studies to adapt to the context of the research. The push effect in this study consists of the pricing problem factor (Vyas and Aratani, 2014), processing problem (Maier, 2016) and service quality (Vyas and Aratani, 2014). The pull effect consists of the easy process factor (Maier, 2016), ease of use (Ye and Potter, 2011) and pricing benefit (Vyas and Aratani, 2014). Meanwhile, the mooring effect consists of the factors of inertia (Li, 2018), security (Ye and Potter, 2011), service products (Vyas and Aratani, 2014) and reputation (Vyas and Aratani, 2014).

The PPM theory is a very dominant theory used to analyze the phenomenon of customer switching that has been used in a variety of research contexts such as the customer switching in the aviation industry by Jung et al. (2017), the customer switching in the hospitality industry by Yan et al. (2019), the customer switching in the manufacturing industry by Suh and Kim (2018), the switching of social media users by Hwang et al. (2018), the switching of cloud storage users by Cheng (2019) and others.

\subsection{Previous Studies}

As explained in the introduction that the study on switching intentions among banking customers to the financing services of Fintech lending is limited which requires further study to examine and analyze the phenomenon of the potential of customer switching among banking customers to the Fintech lending financing services. In this section is explained regarding the two previous study results in accordance with the context of this study so that it can formulate research gaps and novelties.

Maier (2016) conducted study on the phenomenon of customer switching among banking customers on crowdlending services using four dimensions namely technical dimension, functional dimension, image and innovativeness and concluded that the convenience and transparency factors which are the factor of the functional dimension has significant effect on switching intentions. Innovativeness dimension is also known to have significant effect on switching intentions. Meanwhile, the technical and image dimension are known to have no significant effect on switching intentions.

Lindner (2018) also conducted research on the phenomenon of customer switching among banking customers on Fintech lending financing services using qualitative research approach with grounded theory method based on PPM theory and concluded that in the perspective of push effects, the 
Afandi $\mid$ Switching Intentions among Millennial Banking Customers to Fintech Lending

factors affecting of customer switching include such as bad reputation, high price and inefficiency. In the perspective of pull effects, the factors affecting of customer switching include such as the regulation/portfolio sales, visibility and digitization. Meanwhile, in the perspective of mooring effects, the factors that affecting of customer switching include such as launching pad, access and cheaper.

Both studies, using the research object in the form of MSMEs yet to other types of customers such as individual customers. Therefore, to fill the research gap and create novelty, this study used is an individual customer with a category of millennials which became the highest proportion of Indonesian population age today. In addition, this study used a quantitative approach by adopting PPM theory since it is the dominant paradigm in migration literature to answer the phenomenon of customer switching (Jung et al., 2017).

\subsection{Hypothesis Development}

The association between pricing problem and switching intentions

The pricing problem relates to the customer's perception of the pricing policy imposed by the bank (Vyas and Raitani, 2014). The more negative the perception of a banking customer towards the pricing factor, there will be an increasing in the potential of customer switching to the financing services of Fintech lending. Therefore, the hypotheses proposed in this study is:

$\mathrm{H}_{1}$ : pricing problem factor has positive and significant effect on millennial banking customer switching intentions to switch to the financing services of Fintech lending in Indonesia

The association between processing problem and switching intentions

The processing problem factor relates to the inherent perception in a service user to the procedures or terms of service she/he uses (Maier, 2016). Increasingly negative perceptions of banking customers to the procedure or requirement of bank's financing will increase the potential of customer switching to the financing service of Fintech lending. Therefore, the hypotheses proposed in this study is:

$\mathrm{H}_{2}$ : processing problem factor has positive and significant effect on millennial banking customer switching intentions to switch to the financing services of Fintech lending in Indonesia

The association between service quality and switching intentions

The service quality factor relates to the perception of the banking customers to the services who she/he enjoys (Vyas and Raitani, 2014). Service quality in a banking highly determines the loyalty of its customers (Vyas and Raitani, 
Afandi $\mid$ Switching Intentions among Millennial Banking Customers to Fintech Lending

2014). Increasingly negative perceptions of banking customers towards banking services, then the potential of customer switching will be greater. Therefore, the hypotheses proposed in this study is:

$\mathrm{H}_{3}$ : service quality factor has positive and significant effect on millennial banking customer switching intentions to switch to the financing services of Fintech lending in Indonesia

The association between easy process and switching intentions

According to Maier (2016), the easy process factor is one of the hallmarks of Fintech lending that triggers banking customers to switch to the use of Fintech lending services. All of the procedures in financing services of Fintech lending use Internet-based technology media by utilizing a website or application platform to facilitate the borrowing process and the process is more transparent (Maier, 2016). Therefore, the hypotheses proposed in this study is:

$\mathrm{H}_{4}$ : easy process factor has positive and significant effect on millennial banking customer switching intentions to switch to the financing services of Fintech lending in Indonesia.

The association between ease of use and switching intentions

The ease of use factor is a perception of prospective service users to the ease received from the use of a service. According to Ye and Potter (2011), the more prospective users of the service have an easy perception of a service as compared to the alternative services used today it will magnify the chances of switching to a service that is considered easier to use. Therefore, the hypotheses proposed in this study is:

$\mathrm{H}_{5}$ : ease of use factor has positive and significant effect on millennial banking customer switching intentions to switch to the financing services of Fintech lending in Indonesia.

The association between pricing benefit and switching intentions

The pricing benefit factor is the inverse of the pricing problem factor where the perception of a prospective user towards the intended service is positive because the pricing policy set by the service provider is cheaper so it attracts prospective users of services to switch from the currently used services to other services (Vyas and Raitani, 2014). Therefore, the hypotheses proposed in this study is:

$\mathrm{H}_{6}$ : pricing benefit factor has positive and significant effect on millennial banking customer switching intentions to switch to the financing services of Fintech lending in Indonesia. 
Afandi $\mid$ Switching Intentions among Millennial Banking Customers to Fintech Lending

The association between inertia and switching intentions

The factor of inertia is an intentional and conscious process that is done by the user to use the product or service offered by the service provider ( $\mathrm{Li}$, 2018). Someone with a high level of inertia will generally still use the current product or service even if there are products or services offered by a better service provider. Therefore, the hypotheses proposed in this study is:

$\mathrm{H}_{7}$ : inertia factor has negative and significant effect on millennial banking customer switching intentions to switch to the financing services of Fintech lending in Indonesia.

The association between security and switching intentions

The factor of security is a perception of prospective users' service to the security of transactions and the risks offered by service providers. According to Ye and Potter (2011), security factors are very important aspect that must be secured by the service provider regarding transaction security, user data and risk aspects. Therefore, the hypotheses proposed in this study is:

$\mathrm{H}_{8}$ : security factor has positive and significant effect on millennial banking customer switching intentions to switch to the financing services of Fintech lending in Indonesia.

The association between service products and switching intentions

The service products factor is related to the innovation of products or services offered by service providers that affect a person to purchase or use a product or service. According to Vyas and Raitani (2014), the service products factor is very crucial in a business that can determine the sustainability of the business. Therefore, the hypotheses proposed in this study is:

$\mathrm{H}_{9}$ : service products factor has positive and significant effect on millennial banking customer switching intentions to switch to the financing services of Fintech lending in Indonesia.

The association between reputation and switching intentions

Reputation factor is the perception or image of a prospective user of service to a service provider. Reputation factor will generally impact the service user's trust in service providers (Vyas and Raitani, 2014). The reputation factor is indispensable to the service provider as an asset to compete in a competitive marketplace. Therefore, the hypotheses proposed in this study is: 
Afandi $\mid$ Switching Intentions among Millennial Banking Customers to Fintech Lending

$\mathrm{H}_{10}$ : reputation factor has positive and significant effect on millennial banking customer switching intentions to switch to the financing services of Fintech lending in Indonesia

\subsection{Conceptual Framework}

Based on the hypotheses proposed above, the research framework used in this study demonstrated in Figure 1. This framework is modified from PPM theory which was developed by Bansal et al. (2005) to examine regarding switching intentions among millennial banking customers to the financing services of Fintech lending in Indonesia which was caused by three effects of PPM namely push, pull and mooring effects. Push effects are consisted by the negative factors of banking services namely pricing problem, processing problem and service quality which encourage millennial banking customers to switch. Pull effects are consisted by the positive factors of Fintech lending services namely easy process, ease of use and pricing benefit which encourage them to switch. While, mooring effects are factors that can inhibit millennial banking customers to switch because of the negative factors of Fintech lending services consisted by inertia, security, service products and reputation.

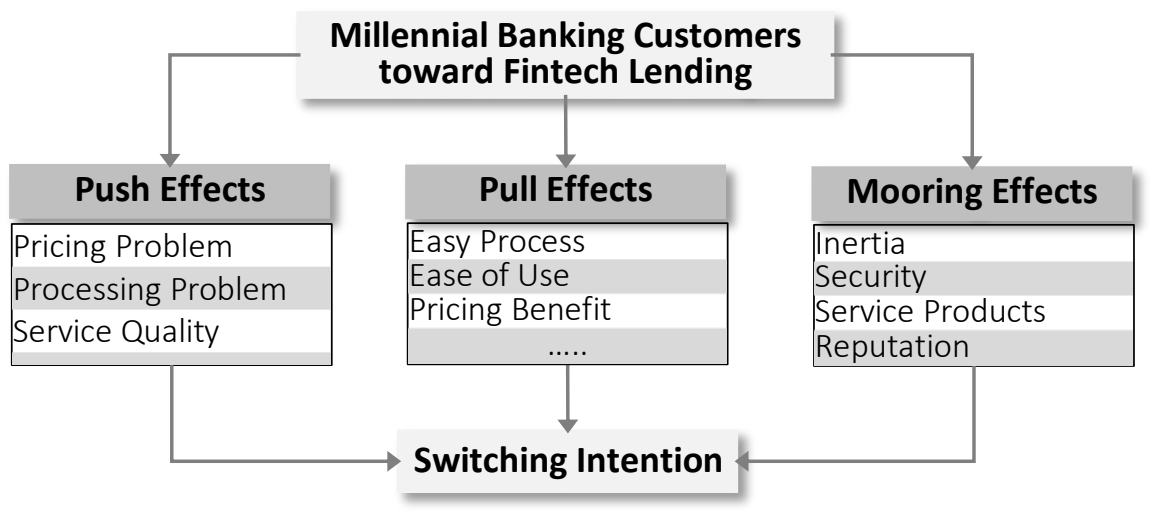

Source: Modified from Bansal et al. (2005)

Figure 1. Research Framework

\section{Methodology}

\subsection{Data}

This study uses research design using a quantitative approach aimed at examining and analyzing the factors affecting of switching intentions among millennial banking customers to the financing services of Fintech lending. This study is conducted using the sample criteria namely banking customers who have made credit/financing at conventional commercial banks or Islamic commercial banks within the last 5 years, aged 18 to 39 years old as a 
Afandi $\mid$ Switching Intentions among Millennial Banking Customers to Fintech Lending

representation of the millennial age and know but have not used the financing services of Fintech lending.

The data collection techniques used in this study were surveying techniques using the Likert 5 scale category $(1=$ "strongly disagree" to $5=$ "strongly agree") which were collected online during the period of October 17th November 22nd, 2019. All research questions used adopted the PPM framework developed by Bansal et al. (2005). A total of 245 primary data was successfully gathered from respondents who had answered all research questions based on their experience.

\subsection{Model Development}

Once the data has been collected, the test factor is carried out from the Kaiser-Meyer-Olkin (KMO) test, anti-image matrices, communalities and component matrix as the validity test. As for the reliability test using Cronbach's alpha test (Malhotra, 2019).

After testing the factor analysis, then conducted testing of Ordinary Least Square (OLS) using the software of SPSS 16.0. According to Bansal et al. (2005), PPM framework has three effects namely push, pull and mooring effects reflecting independent variables which trigger switching intentions reflecting dependent variable. The OLS model used is written in the following regression models:

$Y_{i}=b_{0}+b_{1} X_{1 i}+b_{2} X_{2 i}+b_{3} X_{3 i}+b_{4} X_{4 i}+b_{5} X_{5 i}+b_{6} X_{6 i}+b_{7} X_{7 i}+$ $b_{8} X_{8 i}+b_{9} X_{9 i}+b_{10} X_{10 i}+b_{11} X_{11 i}+e_{i}$

(1)

where:

$\mathrm{Y}_{i} \quad$ = switching intentions

i. number of observations (245 samples)

$\mathrm{b}_{0} \quad=$ constant

$\mathrm{X}_{1 \mathrm{i}} \quad=$ dummy bank used $(0=$ conventional bank, 1 = Islamic bank $)$

$\mathrm{X}_{2 \mathrm{i}} \quad=$ pricing problem

$\mathrm{X}_{3 \mathrm{i}} \quad=$ processing problem

$\mathrm{X}_{4 \mathrm{i}} \quad=$ service quality

$\mathrm{X}_{5 i} \quad=$ easy process

$X_{6 i} \quad=$ ease of use

$X_{7 i} \quad=$ pricing benefit

$X_{8 i} \quad=$ inertia

$X_{9 i} \quad=$ security

$X_{10 i}=$ service products

$\mathrm{X}_{11 \mathrm{i}} \quad=$ reputation

$\mathrm{e}_{\mathrm{i}} \quad=$ error term

\section{3. $\quad$ Method}

This study is used the Ordinary Least Square (OLS) as a method. OLS is a regression model by using independent variables of more than one variable. This method is commonly used to determine the relationship 
Afandi $\mid$ Switching Intentions among Millennial Banking Customers to Fintech Lending

between independent variables and dependent variable and also used as preliminary research to determine the new advanced model (Abduh et al. 2013). In the OLS model have some problems which can interfere with the accuracy of the model made. The problems in the OLS model are the multicollinearity, heteroskedasticity, autocorrelation and normality. To ensure that no problems in the OLS model can be detected through the value of variance Inflation Factor (VIF) and tolerance approaching 1 to be free from multicollinearity, the plot on the resulting chart does not form a specific pattern (random) for homoscedasticity, the value of DurbinWatson (DW) approaches 2 to be free from the autocorrelation and residual forming a normal distribution bell pattern as well as the plot are along the lines for normality (Calen et al. 2018).

\section{Results and Analysis}

\subsection{Result}

\subsubsection{Profile of Respondents}

Prior to process and to analyze data using OLS model, it is necessary to conduct the description of the respondent's profile used in accordance with Table 1.

Table 1 informs that the majority of respondents are male genders with a total of 149 people. The age of majority of respondents is at a range of 30 to 39 years old, which is 136 people. The Domicile of the respondent was scattered in 22 regions in Indonesia but most are domiciled in DKI Jakarta (65 people), Yogyakarta (38 people), Bekasi (31), Tangerang (26 people), Lampung (14 people), Malang (13 people), Bandung (11 people) and Bogor (11 people). In addition, the majority of respondents ended his education at bachelor degree and worked as an employee on the public or private sectors with a monthly income of IDR 1.6 - IDR 4.5 Million. 172 respondents admitted as Muslim and 150 people claimed to have been credit at the conventional banks and 95 people claimed to have been financing at the Islamic banks within the last 5 years. 
Afandi Switching Intentions among Millennial Banking Customers to Fintech Lending

Table 1. Profile of Respondents ( $N=245)$

\begin{tabular}{|c|c|c|c|}
\hline Variable & Category & Frequency & Percentage \\
\hline \multirow[t]{2}{*}{ Gender } & Male & 149 & 60.8 \\
\hline & Female & 96 & 39.2 \\
\hline \multirow[t]{2}{*}{ Age } & $20-29$ & 109 & 44.5 \\
\hline & $30-39$ & 136 & 55.5 \\
\hline \multirow[t]{22}{*}{ Domicile } & Aceh & 2 & 0.8 \\
\hline & Bandung & 11 & 4.5 \\
\hline & Banjarmasin & 1 & 0.4 \\
\hline & Banten & 1 & 0.4 \\
\hline & Bekasi & 31 & 12.7 \\
\hline & Bogor & 11 & 4.5 \\
\hline & Cirebon & 1 & 0.4 \\
\hline & DKI Jakarta & 65 & 26.5 \\
\hline & Jambi & 2 & 0.8 \\
\hline & Kebumen & 1 & 0.4 \\
\hline & Lampung & 14 & 5.7 \\
\hline & Lombok & 2 & 0.8 \\
\hline & Madiun & 1 & 0.4 \\
\hline & Malang & 13 & 5.3 \\
\hline & Medan & 4 & 1.6 \\
\hline & NTT & 2 & 0.8 \\
\hline & Padang & 3 & 1.2 \\
\hline & Palembang & 2 & 0.8 \\
\hline & Sumedang & 8 & 3.3 \\
\hline & Surabaya & 6 & 2.4 \\
\hline & Tangerang & 26 & 10.6 \\
\hline & Yogyakarta & 38 & 15.5 \\
\hline \multirow[t]{4}{*}{ Education Level } & High school or below & 38 & 15.5 \\
\hline & Diploma & 47 & 19.2 \\
\hline & Bachelor degree & 141 & 57.6 \\
\hline & Master of doctoral degree & 19 & 7.8 \\
\hline \multirow[t]{3}{*}{ Profession } & Entrepreneur & 26 & 10.6 \\
\hline & $\begin{array}{l}\text { Staff on private or public } \\
\text { sectors }\end{array}$ & 163 & 66.5 \\
\hline & Housewife & 30 & 12.2 \\
\hline \multirow[t]{4}{*}{ Income per Month } & $\leq$ IDR 1.5 Million & 13 & 5.3 \\
\hline & IDR 1.6 - IDR 4.5 Million & 112 & 45.7 \\
\hline & IDR 4.6 - IDR 10 Million & 98 & 40 \\
\hline & > IDR 10 Million & 22 & 9 \\
\hline \multirow[t]{3}{*}{ Religion } & Islam & 172 & 70.2 \\
\hline & Catholic & 30 & 12.2 \\
\hline & Protestant & 43 & 17.6 \\
\hline \multirow[t]{2}{*}{ Bank Used } & Conventional bank & 150 & 61.2 \\
\hline & Islamic bank & 95 & 38.8 \\
\hline
\end{tabular}

Source: Computed by author (2019) 
Afandi $\mid$ Switching Intentions among Millennial Banking Customers to Fintech Lending

\subsubsection{Factor Analysis Tests}

The factor analysis test serves to test the validity and reliability of any research question in the proposed questionnaire. The validity and reliability test outputs are shown in Table 2 and Table 3.

Table 2. Output of Validity Tests

\begin{tabular}{|c|c|c|c|c|c|}
\hline Variable & Indicators & KMO & $\begin{array}{l}\text { Anti-Image } \\
\text { Matrices }\end{array}$ & Communalities & $\begin{array}{c}\text { Component } \\
\text { Matrix }\end{array}$ \\
\hline \multirow[t]{4}{*}{ Pricing Problem } & Item1 & \multirow{4}{*}{0.802} & 0.833 & 0.720 & 0.849 \\
\hline & Item2 & & 0.843 & 0.750 & 0.866 \\
\hline & Item3 & & 0.777 & 0.830 & 0.911 \\
\hline & Item4 & & 0.772 & 0.848 & 0.921 \\
\hline Processing & Item5 & \multirow{5}{*}{0.871} & 0.819 & 0.959 & 0.979 \\
\hline \multirow[t]{4}{*}{ Problem } & Item6 & & 0.890 & 0.933 & 0.966 \\
\hline & Item7 & & 0.945 & 0.842 & 0.917 \\
\hline & Item8 & & 0.844 & 0.946 & 0.973 \\
\hline & Item9 & & 0.879 & 0.794 & 0.891 \\
\hline \multirow[t]{6}{*}{ Service Quality } & Item10 & \multirow{6}{*}{0.685} & 0.617 & 0.903 & 0.818 \\
\hline & Item11 & & 0.616 & 0.947 & 0.814 \\
\hline & Item12 & & 0.866 & 0.686 & 0.828 \\
\hline & Item13 & & 0.724 & 0.531 & 0.728 \\
\hline & Item14 & & 0.659 & 0.889 & 0.766 \\
\hline & Item15 & & 0.698 & 0.930 & 0.835 \\
\hline \multirow[t]{6}{*}{ Easy Process } & Item16 & \multirow{6}{*}{0.754} & 0.823 & 0.693 & 0.832 \\
\hline & Item17 & & 0.764 & 0.597 & 0.630 \\
\hline & Item18 & & 0.748 & 0.502 & 0.709 \\
\hline & Item19 & & 0.926 & 0.765 & 0.875 \\
\hline & Item20 & & 0.648 & 0.727 & 0.853 \\
\hline & Item21 & & 0.690 & 0.802 & 0.895 \\
\hline \multirow[t]{3}{*}{ Ease of Use } & Item22 & \multirow{3}{*}{0.730} & 0.666 & 0.955 & 0.977 \\
\hline & Item23 & & 0.660 & 0.958 & 0.979 \\
\hline & Item24 & & 0.950 & 0.870 & 0.933 \\
\hline \multirow[t]{3}{*}{ Pricing Benefit } & Item25 & \multirow{3}{*}{0.714} & 0.805 & 0.761 & 0.872 \\
\hline & Item26 & & 0.712 & 0.823 & 0.907 \\
\hline & Item 27 & & 0.655 & 0.880 & 0.938 \\
\hline \multirow[t]{4}{*}{ Inertia } & Item28 & \multirow{4}{*}{0.746} & 0.816 & 0.566 & 0.605 \\
\hline & Item29 & & 0.693 & 0.859 & 0.927 \\
\hline & Item30 & & 0.699 & 0.837 & 0.915 \\
\hline & Item31 & & 0.852 & 0.802 & 0.896 \\
\hline \multirow[t]{3}{*}{ Security } & Item32 & \multirow{3}{*}{0.634} & 0.746 & 0.627 & 0.792 \\
\hline & Item33 & & 0.586 & 0.872 & 0.934 \\
\hline & Item34 & & 0.627 & 0.769 & 0.877 \\
\hline Service & Item35 & \multirow{3}{*}{0.702} & 0.792 & 0.695 & 0.834 \\
\hline \multirow[t]{2}{*}{ Products } & Item36 & & 0.653 & 0.829 & 0.911 \\
\hline & Item37 & & 0.693 & 0.777 & 0.881 \\
\hline \multirow[t]{3}{*}{ Reputation } & Item38 & \multirow{3}{*}{0.669} & 0.843 & 0.731 & 0.855 \\
\hline & Item39 & & 0.606 & 0.926 & 0.962 \\
\hline & Item40 & & 0.640 & 0.878 & 0.937 \\
\hline
\end{tabular}

Source: Computed by author (2019) 
Afandi $\mid$ Switching Intentions among Millennial Banking Customers to Fintech Lending

Table 2 explains that based on the validity test, all research questions have a value of $\mathrm{KMO}>0.5$, anti-image matrices $>0.5$, communalities $>$ 0.5 and component matrix $>0.5$ which means that all research questions have fulfilled the validity test or the entire list of research questions can be said to have been appropriately used as measuring of research variable and can be continued to the next test namely reliability test.

Table 3. Output of Reliability Test

\begin{tabular}{ccc}
\hline Cronbach's Alpha & Cronbach's Alpha Based on Standardized Items & N of Items \\
\hline 0.862 & 0.856 & 40 \\
\hline
\end{tabular}

Source: Computed by author (2019)

Table 3 shows the reliability test output using the value of Cronbach's alpha. Based on Cronbach's alpha value, the whole research question has fulfilled the assumption of the reliability test due to the value of Cronbach's alpha $>0.6$ or in other words the respondents have answered the research questions consistently.

\subsubsection{Ordinary Least Square (OLS)}

After all research questions meet the assumption of the validity and reliability test or it is said to be valid and reliable, then the data processing can be conducted using the OLS model as shown in Table 4.

Table 4. Output of Ordinary Least Square (OLS)

\begin{tabular}{|c|c|c|c|c|c|}
\hline \multirow[t]{2}{*}{ Model } & \multicolumn{2}{|c|}{$\begin{array}{l}\text { Unstandardized } \\
\text { Coefficients }\end{array}$} & \multirow{2}{*}{$\begin{array}{c}\begin{array}{c}\text { Standardized } \\
\text { Coefficients }\end{array} \\
\text { Beta }\end{array}$} & \multirow[t]{2}{*}{$\mathrm{t}$} & \multirow[t]{2}{*}{ Sig. } \\
\hline & $\mathrm{B}$ & Std. Error & & & \\
\hline (Constant) & -0.091 & 1.476 & & -0.061 & 0.951 \\
\hline Dummy Bank Used & 0.729 & 0.256 & 0.151 & 2.852 & 0.005 \\
\hline Pricing Problem & 0.068 & 0.040 & 0.088 & 1.709 & 0.089 \\
\hline Processing Problem & 0.036 & 0.029 & 0.073 & 1.246 & 0.214 \\
\hline Service Quality & -0.029 & 0.028 & -0.049 & -1.002 & 0.317 \\
\hline Easy Process & 0.078 & 0.048 & 0.095 & 1.621 & 0.106 \\
\hline Ease of Use & 0.420 & 0.071 & 0.352 & 5.950 & 0.000 \\
\hline Pricing Benefit & 0.352 & 0.068 & 0.292 & 5.143 & 0.000 \\
\hline Inertia & -0.054 & 0.040 & -0.067 & -1.361 & 0.175 \\
\hline Security & 0.105 & 0.068 & 0.114 & 1.537 & 0.126 \\
\hline Service Products & -0.164 & 0.057 & -0.152 & -2.878 & 0.004 \\
\hline Reputation & -0.162 & 0.056 & -0.199 & -2.886 & 0.004 \\
\hline R Square & 0.565 & & & & \\
\hline
\end{tabular}

Source: Computed by author (2019)

From Table 4 above can be written the OLS model in this study:

Switching Intentions $=$

$-0.091+0.0729$ Bank Used +0.068 Pricing Problem +0.036

Processing Problem -0.029 Service Quality +0.078 Easy Process +

0.420 Ease of Use +0.352 Pricing Benefit -0.054 Inertia +0.105 Security- 0.164 Service Products -0.162 Reputation $+\mathrm{e}$ 
Afandi Switching Intentions among Millennial Banking Customers to Fintech Lending

The resulting of OLS model can be done of model interpretations:

a. The value of constant of -0.091 means that the average of switching intentions of millennial conventional banking customers to switch to the financing services of Fintech lending.

b. Value $b_{1}$ variable of dummy bank used of 0.729 means that the average of switching intentions of millennial Islamic banking customers higher than the average of switching intentions of millennial conventional banking customers as big as 0.729 times to switch to the financing services of Fintech lending. With $p$-value of 0.005 means $H_{0}$ is rejected or in other words there is a significant difference between millennial Islamic banking customers and millennial conventional banking customers to switch to the financing services of Fintech lending.

c. Value $b_{2}$ variable of pricing problem of 0.068 means that every increasing in the negative perception of pricing problem in credit/financing services of banking will increase the switching intentions of millennial banking customers to the financing services of Fintech lending by 0.068 percent. With p-value of 0.089 means that $\mathrm{H}_{0}$ is received or in other words the pricing problem has positive but not significant effect on switching intentions.

d. Value $b_{3}$ variable of processing problem of 0.036 means that every increasing in the negative perception of processing problem in credit/financing services of banking will increase the switching intentions of millennial banking customers to the financing services of Fintech lending by 0.036 percent. With p-value of 0.214 means that $\mathrm{H}_{0}$ is received or in other words the processing problem has positive but not significant effect on switching intentions.

e. Value $b_{4}$ variable of service quality of -0.029 means that the service quality in credit/financing services in banking services is considered to be good enough so as to reduce the switching intentions of millennial banking customers to the financing services of Fintech lending by -0.029 percent. With $p$-value of 0.317 means that $H_{0}$ is received or in other words the service quality has negative and not significant effect on switching intentions.

f. Value $b_{5}$ variable of easy process of 0.078 means that every increasing in the positive perception of easy process in credit/financing services of Fintech lending will increase the switching intentions of millennial banking customers to the financing services of Fintech lending by 0.078 percent. With $p$-value of 0.106 means that $\mathrm{H}_{0}$ is received or in other words the easy process has positive but not significant effect on switching intentions.

g. Value $b_{6}$ variable of ease of use of 0.420 means that every increasing in the positive perception of ease of use in credit/financing services of Fintech lending will increase the switching intentions of millennial banking customers to the financing services of Fintech lending by 0.420 percent. With $p$-value of 0.000 means that $H_{0}$ is rejected or in other words the ease of use has positive and significant effect on switching intentions. 
Afandi $\mid$ Switching Intentions among Millennial Banking Customers to Fintech Lending

h. Value $b_{7}$ variable of pricing benefit of 0.352 means that every increasing in the positive perception of pricing benefit in credit/financing services of Fintech lending will increase the switching intentions of millennial banking customers to the financing services of Fintech lending by 0.352 percent. With $p$-value of 0.000 means that $H_{0}$ is rejected or in other words the pricing benefit has positive and significant effect on switching intentions.

i. Value $b_{8}$ variable of inertia of -0.054 means that every increasing of inertia towards credit/financing services of banking will decrease the switching intentions of millennial banking customers to the financing services of Fintech lending by -0.054 percent. With $p$-value of 0.175 means that $\mathrm{H}_{0}$ is received or in other words the inertia has negative and not significant effect on switching intentions.

j. Value $b_{9}$ variable of security of 0.105 means that the security factor in the financing services of Fintech lending is deemed to have been good enough so as not to degrade and precisely increase the switching intentions of millennial banking customers to the financing services of Fintech lending by 0.105 percent. With p-value of 0.126 means that $\mathrm{H}_{0}$ is received or in other words the security has positive but not significant effect on switching intentions.

k. Value $b_{10}$ variable of service products of -0.164 means that every increasing in the negative perception of service products in credit/financing services of Fintech lending will decrease the switching intentions of millennial banking customers to the financing services of Fintech lending by -0.164 percent. With p-value of 0.004 means that $\mathrm{H}_{0}$ is rejected or in other words the service products have negative and significant effect on switching intentions.

I. Value $b_{11}$ variable of reputation of -0.162 means that every increasing in the negative perception of reputation in credit/financing services of Fintech lending will decrease the switching intentions of millennial banking customers to the financing services of Fintech lending by 0.162 percent. With $p$-value of 0.004 means that $H_{0}$ is rejected or in other words the reputation has negative and significant effect on switching intentions.

$\mathrm{m}$. The $\mathrm{R}$ square value of 0.565 means that all independent variables are able to explain the variation of the dependent variable which is switching intentions as big as 56.5 percent, while the remainder of 43.5 percent is explained by other variables that are not calculated in the model. 
Afandi $\mid$ Switching Intentions among Millennial Banking Customers to Fintech Lending

Table 5. Output of Multicollinearity and Autocorrelation Tests

\begin{tabular}{ccc}
\hline \multicolumn{2}{c}{ Collinearity Statistics } & \multicolumn{2}{c}{ Durbin-Watson } \\
\hline Tolerance & VIF & 1.628 \\
0.669 & 1.494 & \\
0.703 & 1.423 & 1.819 \\
0.774 & 1.292 & \\
0.546 & 1.832 & \\
0.532 & 1.878 & \\
0.579 & 1.727 & \\
0.761 & 1.314 & \\
0.341 & 2.936 & \\
0.672 & 1.487 & \\
0.394 & 2.538 & \\
\hline
\end{tabular}

Source: Computed by author (2019)

The resulting OLS model has been freed from the problem of multicollinearity and autocorrelation that can be known from the value of VIF and tolerance which are close to 1 and the DW value approaching 2 . Whereas, normality and heteroscedasticity are shown in Figure 2.

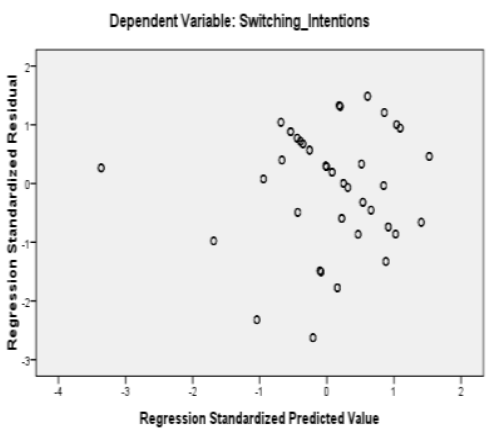

(a)

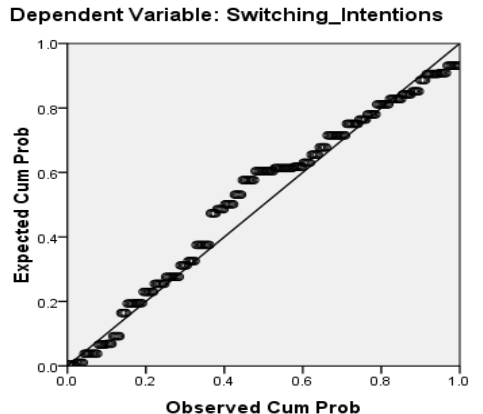

(b)

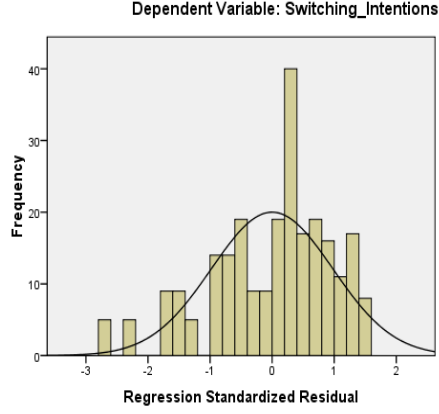

(c)

Figure 2. Output of Normality and Heteroscedasticity Tests

Source: Computed by author (2019)

Figure 2 explains that the resulting OLS model has fulfilled the assumption of normality which can be known from Figure 2(a) which is the residual forming normal distribution pattern of bell-shaped and Figure 2(b) which the plot in the image is not far from the line (Nachrowi and Usman, 2018). In addition, the resulting OLS model has fulfilled the assumption of homoscedasticity which can be known from Figure 2(c) which the plot in the image is not form a particular pattern or in other words the residual is not heteroscedasticity.

\subsection{Analysis}

Based on the results of the study above, it can be done analysis of the following study results:

Millennial Islamic banking customers are known to have higher the average of switching intentions than the millennial conventional banking customers to switch to the financing services of Fintech lending. The 
Afandi $\mid$ Switching Intentions among Millennial Banking Customers to Fintech Lending

Results of this study confirm the study conducted by Afandi and Muta'ali (2019) explained that millennial Islamic banking have the opportunity to switch to the financing services of Fintech lending higher than the millennial conventional banking customers due to the lower level of inertia of millennial Islamic banking customers than the millennial conventional banking customers.

In the perspective of push effects that consists of the pricing problem, processing problem and service quality factors can be noted that each factor does not have a significant effect on switching Intentions. The results were not in accordance with the results of the study conducted by Jung et al. (2017); Li (2018); Li and Ku (2018) explained that the push factor has significant effect on switching intentions. In other words, the result of this study provides evidence that the millennial banking customers tend to have a positive perception of credit/financing services in banking in the aspect of pricing, processing and service quality so as not to encourage them to switch to the financing services of Fintech lending.

In the perspective of pull effects, only the ease of use and pricing benefit factors are significant impact on switching intentions so that it attracts the millennial banking customers to switch to the financing services of Fintech lending. The Results of this study correspond to the results of study conducted by Jung et al. (2017); Li (2018); Li and Ku (2018) explained that the pull factor has significant effect on switching intentions. The use of technology is an advantage of Fintech lending which causes its services to have characteristics such as ease, speed, flexibility and sufficient information so as to influence the person's perception to switch using Fintech lending services (Maier, 2016). In addition, the use of technology also leads to more efficient of Fintech lending services so as to reduce of operational costs impacting the price of products that are cheaper than credit/financing services in banking (Lindner, 2018).

Meanwhile, in the perspective of mooring effects is only factor of service products and reputation which are known to have significant effect on switching intentions that could impede millennial banking customers to switch to the financing services of Fintech lending. The results of this study confirm the results of study conducted by Jung et al. (2017); Sun et al. (2017); Li (2018) explained that the mooring factor has significant effect on switching Intentions. The result of this study also proves that the level of inertia of millennial banking customers are high enough that can be known from the negative axis of inertia towards switching intentions that it can reduce their motivation to find information about other products or services so as to inhibit them to switch (Li, 2018). In addition, the service products and reputation factors are also the factor which can inhibit the switching intentions among millennial banking customers to the financing services of Fintech lending which means they have the perception that Fintech lending products or services have yet 
Afandi $\mid$ Switching Intentions among Millennial Banking Customers to Fintech Lending

to fit their needs and the reputation of Fintech lending in the eyes of prospective users has not been so good.

\section{Conclusions and Recommendations}

\subsection{Conclusions}

Based on the results and discussions that has been done can be concluded that in the perspective of push effects, each of push factor consisting of pricing problem, processing problem and service quality has no significant effect on switching intentions of millennial banking customers to the financing services of Fintech lending or in other words credit/financing services in banking is taken into account quite good so that it does not encourage them to switch to the financing services of Fintech lending.

In the perspective of pull effects is known only the ease of use and pricing benefit factors that have significant effect on switching intentions of millennial banking customers to switch to the financing services of Fintech lending. This result proves that the use of technology in the operations of Fintech lending provides more benefits and gave positive response by prospective users so as to attract them to use Fintech lending services.

In the perspective of mooring effects is only factor of service products and reputation that have significant effect on switching intentions of millennial banking customers to switch to the financing services of Fintech lending. This result also proves that the level of inertia of millennial banking customers is quite high coupled with a perception that has not been so good against the factors of service products and reputation on the financing services of Fintech lending so as to impede the millennial banking customers to switch to the financing services of Fintech lending.

In addition, one of the results of this study can be known that the average of switching intentions among millennial Islamic banking customer are higher than the average of switching intentions among millennial conventional banking customers which can be an important information for the managerial parties of Islamic banking.

\subsection{Recommendations}

The results of this study are expected to provide useful information for the managerial banks, Fintech lending, regulators and other researchers to be able to determine effective strategies and policies as well as research development amid the occurrence of disruption in banking services due to the presence of Fintech lending especially in the aspect of customer switching. Therefore, the banking industry and Fintech lending is recommended to conduct a partnership model amid the competitive advantages that each has so that it can receive benefits and minimizing of losses due to customer switching and tougher business competition. That 
Afandi $\mid$ Switching Intentions among Millennial Banking Customers to Fintech Lending

partnership model needs to be governed by the regulator in this case is the Financial Services Authority. In addition, for further research development, researchers are expected to add a sample of research used with a more equitable distribution of samples in each province in Indonesia to provide more representative research results. Research development can also be done by adding other factors to each PPM effects.

\section{References}

Abduh, M., Kassim, S. H., \& Dahari, Z. (2013). Factors Influence Switching Behavior of Islamic Bank Customers in Malaysia. Journal of Islamic Finance, 2(1), $12-19$.

Afandi, M. A., \& Muta'ali, A. (2019). Millennial Banking Customer Perceptions and Its Potential to Switch to Financing Services of Fintech Lending: A Comparative Analysis. Paper presented at The $34^{\text {th }}$ International Business Information Management (IBIMA) Conference, Madrid, Spain.

Al-hawari, M. A. (2014). Emotional stability and switching barriers in the retail banking context. Managing Service Quality: An International Journal, 24(5), $469-486$.

Bakar, J. A., Clemes, M. D., \& Bicknell, K. (2017). A comprehensive hierarchical model of retail banking. International Journal of Bank Marketing, 35(4), $662-684$.

Bansal, H. S., Taylor, S. F., \& James, Y. St. (2005). "Migrating" to New Service Providers: Toward a Unifying Framework of Consumers' Switching Behaviors. Journal of the Academy of Marketing Science, 33(1), 96 115.

Calen., Ade, S., Rosmaneliana, D., \& Evadine, R. (2018). The Impact of Return on Equity (ROE) and Debt to Equity Ratio (DER) toward Change in Profit on the Plantation Company Registered on BEI. International Journal of Management Sciences and Business Research, 7(2), 204 212.

Cheng, S., Lee, S-J., \& Choi, B-J. (2019). An empirical investigation of users' voluntary switching intention for mobile personal cloud storage services based on the push-pull-mooring framework. Computers in Human Behavior, 92, $198-215$.

Dietz, M., Khanna, S., Olanrewaju, T., \& Rajgopal, K. (2016). Cutting through the noise around financial technology. McKinsey\&Company: Fintechnicolor (The New Picture in Finance).

Farah, M. F. (2017a). Application of the theory of planned behavior to customer switching intentions in the context of bank consolidations. International Journal of Bank Marketing, 35(1), 147- 172.

Farah, M. F. (2017b). Consumers' switching motivations and intention in the case of bank mergers : a cross-cultural study. International Journal of Bank Marketing, 35(2), $254-274$.

Hwang, H. S., Shim, J. W., \& Park, S. B. (2018). Why we migrate in the virtual world: factors affecting switching intentions in SNS. Information, Communication \& Society, 22(14), $2127-2137$. 
Afandi $\mid$ Switching Intentions among Millennial Banking Customers to Fintech Lending

Jung, J., Han, H., \& Oh, M. (2017). Travelers' switching behavior in the airline industry from the perspective of the push-pull-mooring framework. Tourism Management, 59, 139 - 153.

Kasali, R. (2018). Self Disruption (Bagaimana Perusahaan Keluar dari Perangkap Masa Lalu dan Mendisrupsi Dirinya Menjadi Perusahaan yang Sehat) [Self Disruption (How Does the Company Get Out from the Trap of the Past and Disrupts Itself to be A Healthy Company)]. Jakarta: Penerbit Mizan Anggota IKAPI.

Kementerian Pemberdayaan Perempuan dan Perlindungan Anak., Badan Pusat Statistik. (2018). Profil Generasi Milenial Indonesia [The Profile of Indonesia's Millennial Generation]. Jakarta: Kementerian Pemberdayaan Perempuan dan Perlindungan Anak.

Koutsothanassi, E., Bouranta, N., \& Psomas, E. (2017). Examining the relationships among service features, customer loyalty and switching barriers in the Greek banking sector. International Journal of Quality and Service Sciences, 9(3/4), $425-440$.

Le Wang., Luo, X. (R)., Yang, X., \& Qiao, Z. (2019). Easy come or easy go? Empirical evidence on switching behaviors in mobile payment applications. Information \& Management, 56(7), 1- 13.

Lee, J., Ryu, M. H., \& Lee, D. (2019). A study on the reciprocal relationship between user perception and retailer perception on platform-based mobile payment service. Journal of Retailing and Consumer Services, $48,7-15$.

Li, C-Y. (2018). Computers in Human Behavior Consumer behavior in switching between membership cards and mobile applications: The case of Starbucks. Computers in Human Behavior, 84, 171- 184.

Li, C-Y., \& Ku, Y-C. (2018). The power of a thumbs-up: Will e-commerce switch to social commerce? Information \& Management, 55, $340-$ 357.

Lindner, M. (2018). Switching behavior phenomenon analysis: SME's switching behavior from traditional financial institutions to Fintech financing (Master Thesis). Amsterdam Business School.

Maier, E. (2016). Supply and demand on crowdlending platforms: Connecting small and medium-sized enterprise borrowers and consumer investors. Journal of Retailing and Consumer Services, 33, 143 - 153.

Malhotra, N. K. (2019). Marketing Research: An Applied Orientation (7th Edition). New York: Pearson.

Nachrowi, N. D., \& Usman, H. (2018). Pendekatan Populer dan Praktis Ekonometrika untuk Analisis Ekonomi dan Keuangan [A Popular and Practical Econometrics Approach for Economic and Financial Analysis]. Jakarta: Lembaga Penerbit Fakultas Ekonomi Universitas Indonesia.

Piha, L. P., \& Avlonitis, G. J. (2015). Customer defection in retail banking Attitudinal and behavioural consequences. Journal of Service Theory and Practice, 25(3), $304-326$.

PricewaterhouseCoopers. (2016). Customers in the spotlight (How Fintech is reshaping banking). PwC: Global Fintech Survey 2016.

Schwab, K. (2016). The Fourth Industrial Revolution. Cologny/Geneva, Switzerland: World Economic Forum. 
Afandi $\mid$ Switching Intentions among Millennial Banking Customers to Fintech Lending

Suh, C. J., \& Kim, J-H. (2018). Buyers' switching intentions in a manufacturing supply chain: a migration theory perspective. International Journal of Operations \& Production Management, 38(12), 2246- 2265.

Sun, Y., Liu, D., Chen, S., Wu, X., Shen, X-L., \& Zhang, X. (2017). Understanding users' switching behavior of mobile instant messaging applications: An empirical study from the perspective of push-pullmooring framework. Computers in Human Behavior, 75, 727 - 738.

TransferWise. (2016). Creating The Perfect Storm. Retrieved December 11, 2019, from https:transferwise.com/gb/blog/creating-the-perfectstorm

Vyas, V., \& Raitani, S. (2014). Drivers of customers' switching behavior in Indian banking industry. International Journal of Bank Marketing, 32(4), $321-342$.

Yan, R., Zhang, K. Z. K., Yu, Y. (2019). Switching from hotels to peer-to-peer accomodation: an empirical study. Information Technology \& People, 32(6), $1657-1678$.

Ye, C., \& Potter, R. (2011). The Role of Habit in Post-Adoption Switching of Personal Information Technologies: An Empirical Investigation. Communications of the Association for Information Systems, 28(35), $585-610$. 
Afandi $\mid$ Switching Intentions among Millennial Banking Customers to Fintech Lending

This page is intentionally left blank

International Journal of Islamic Economics and Finance (IJIEF), 3(2), 283-304 | 304 